\title{
Pre-service teachers' scientific explanation with e-scaffolding in blended learning
}

\author{
Rizki Amelia $^{1^{*}, \text { Imam Rofiki }}{ }^{2}$, Hasan Said TORTOP ${ }^{3}$, Joshua Abah ABAH ${ }^{4}$ \\ ${ }^{1,2}$ Universitas Islam Negeri Maulana Malik Ibrahim Malang, Indonesia \\ ${ }^{3}$ Istanbul Esenyurt University, Turkey \\ ${ }^{4}$ Federal University of Agriculture Makurdi, Nigeria \\ *Corresponding Address: rizkiamelia@uin-malang.ac.id
}

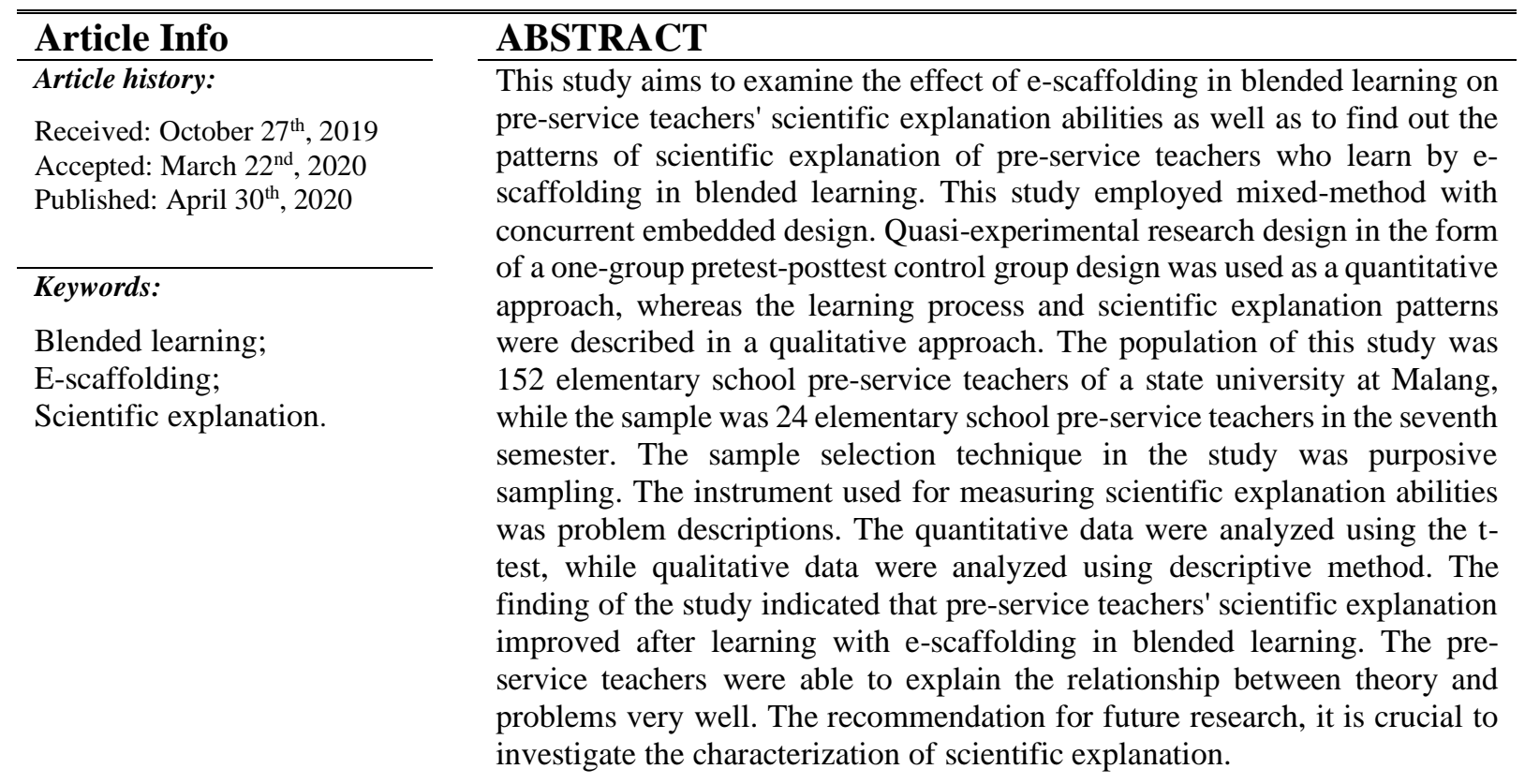

(C) 2020 Physics Education Department, UIN Raden Intan Lampung, Indonesia.

\section{INTRODUCTION}

Science is not only about facts and concepts, but also involves ways of thinking and explaining scientifically. The ability to reason scientifically in science is different from the explanation abilities used in everyday life. The indicator of scientific explanation in science consists of explaining the facts that exist in a problem (claim), connecting these facts with related concepts (evidence), and explaining the problem scientifically (Loper et al., 2019). When a scientist explains a phenomenon, the first step taken is to build a claim, then provide evidence and reasons to justify their statement (González-Howard et al., 2017; McNeill et al., 2018).

The ability of scientific explanation is a crucial ability for a pre-service teacher or prospective teacher. Scientific explanation ability is expected to be taught in class as a provision for students to face the challenges of globalization. Students' scientific explanation ability is very dependent on the ability of the teacher to develop learning that can train their explanation ability (Gunawan, 2016). Thus, the scientific explanation ability of a pre-service teacher should be good, to be able to practice the scientific explanation ability of students. 
Our observation on August 12, 2019, at Universitas Islam Negeri Maulana Malik Ibrahim Malang found that the ability of scientific explanation for elementary school pre-service teachers were not yet developed. Pre-service teachers still did not fully understand the concepts of science. Most of them were correct in explaining the facts that exist in a problem. However, they were confused when they were asked about the reasons for their answers (Probosari et al., 2016; Rofiki et al., 2017a). In general, preservice teachers were able to explain claims and evidence well. However, they feel difficulty in making an explanation (Nurhayati et al., 2016).

One strategy that can optimize pre-service teachers' linking between concepts is scaffolding. Scaffolding can help them explain the interrelationships between concepts (Campbell, 2016), compile claims, evidence, and explanation, to develop their scientific explanation abilities (McNeill et al., 2006). By using scaffolding, students also more easily explain a problem, starting from an understanding problem, connecting among concepts, and giving a reason to answer why a problem occurs (McNeill et al., 2006). Scaffolding is a way to help students build arguments based on the available evidence (Sengul et al., 2019). Therefore, scaffolding can develop scientific explanation abilities.

Nowadays, technology is increasingly developing and influencing human life. The development of technology also has an impact on various fields, one of which is education. As technology grows more rapidly, technology and media in learning even begin to build. One of them is the use of blended learning, which is a combination of offline and online learning (Abdullah, 2018). With the right technology, learners can have a socially supported, exploratory learning experience literally at their fingertips. Blended learning provides a pivotal avenue to enhance learning outcomes, and fully equip students to address $21^{\text {st }}$ century educational needs (Abah et al., 2017; Law et al., 2019).

Successful technology integration is achieved when the use of technology is routine and transparent, accessible, and readily available for the task at hand, supporting the curricular goals and helping students to achieve their own goals effectively. Tech-augmented learning, such as e-scaffolding, seeks to deploy technological tools that are a seamless part of the learning process, almost a second nature to ordinary classroom activities. When tech tools are readily available and efficiently blended into instructional activities, the outcome is often active engagement of learners and the provision of the opportunity to build a deeper understanding of content (Agbo-Egwu et al., 2018).

Blended learning is perfectly matched with scaffolding. Pre-service teachers' performance who learn in blended learning with scaffolding is more optimal compared to those who do not use scaffolding (Kim et al., 2018). It is caused by the environment formed in blended learning that can help them to connect between concepts and improve their understanding of concepts (Deschacht \& Goeman, 2015; Hwang et al., 2019). Thus, it is necessary to investigate further the ability of scientific explanation of pre-service teachers in blended learning with e-scaffolding.

A scientific explanation is a crucial issue that needs to be investigated immediately. Scientific explanation Several previous studies have investigated scientific explanations or scientific arguments (Gilles \& Buck, 2019; Lee et al., 2019; Oktavianti et al., 2018; Pallant \& Lee, 2015). The results of those studies show that good student's scientific explanations support in-depth understanding, and the provision of scaffolding by educators can develop students' scientific explanations. However, there are few studies on scientific explanation and scaffolding associated with technology. Whereas e-scaffolding is significant to develop scientific explanations. 
Our research use e-scaffolding to reveal the scientific explanation of pre-service teachers. We integrate a worksheet on e-learning that provides procedural e-scaffolding to assist pre-service teachers in solving problems.

This study aims to investigate the effect of blended learning with e-scaffolding on the ability of scientific explanation of pre-service teachers as well as to understand the pattern of scientific explanation ability of pre-service teachers who learn using e-scaffolding in blended learning. The results of this study can be used by educators to design learning tools and learning strategies that can develop students' scientific explanations. Also, the results of this study can be used as a source of information for other researchers who are interested in investigating the topics of scientific explanation, e-scaffolding, and blended learning.

\section{METHODS}

This study employed a mixed-method with a Concurrent Embedded Design, a research method that combines quantitative and qualitative approaches (Creswell \& Creswell, 2018). However, in this study, the weight of the quantitative approach was greater than the qualitative approach. The study used a quasi-experimental research design in the form of a one-group pretestposttest control group design as a quantitative approach. A qualitative approach was used to describe the learning process and scientific explanation patterns. The study scheme is presented in Figure 1.

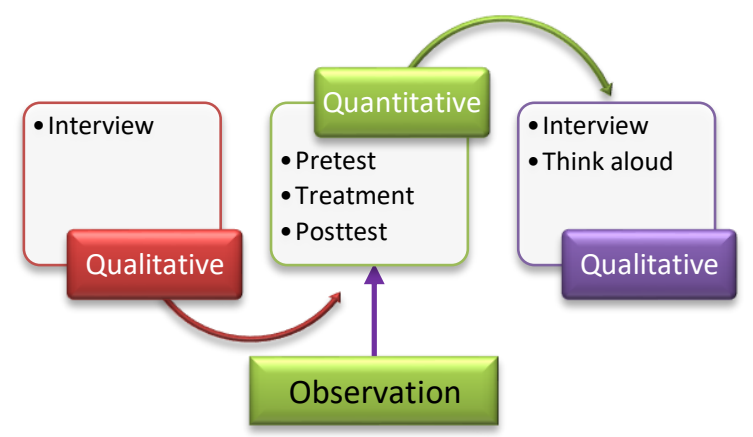

Figure 1. The study scheme

The design of learning in this study was carried out in blended learning, which also involved scaffolding. The teaching was carried out in blended learning using elearning. We designed e-learning that engaged scaffolding to help pre-service teachers if they are unable to understand the concept or experience some difficulties in solving a problem. In e-learning, we constructed three materials, namely motion, force, and energy. We also provided video, the content both on PDF and PowerPoint, discussion forum, and evaluation in every material. For example, the e-learning display on motion material is presented in Figure 2.

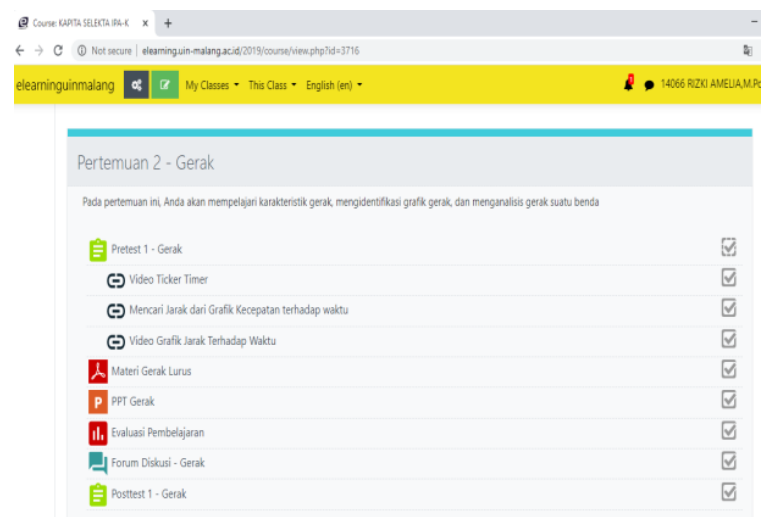

Figure 2. E-learning display on motion material

The population of this study was 152 students of pre-service teachers at Universitas Islam Negeri Maulana Malik Ibrahim Malang. The sample was selected according to needs so that it can achieve the study objective. We chose the sample based on specific requirements such as the preservice teachers who took the specialization of science with the number of pre-service teachers was 24 . Thus, the sample selection technique in this study was purposive sampling. The instrument used to measure the ability of scientific explanation in this study was 12 items of multiple-choice questions.

The analysis of data in this study used both quantitative and qualitative. Quantitative data were analyzed using paired sample t-test with prerequisite tests for normality in advance. The analysis of qualitative data was performed with flow models (Miles et al., 2018) on the results of semi-structured interviews and think aloud. The data was reduced by grouping them into two main groups, namely pre-service teacher behavior 
during the learning process and pre-service teachers' mindset during semi-structured interviews and think aloud. After that, the findings were synthesized to get a general description of scientific ability reflected in preservice teachers' behavior during learning and their mindset during semi-structured interviews and think aloud. In the think-aloud method, someone is asked to express aloud any words that her/his thinking at first receiving a problem to solving the problem (Rofiki et al., 2017b).

\section{RESULTS AND DISCUSSION \\ Pretest and Posttest Scientific Explanation Data}

The scientific explanation test was carried out before and after the treatment was given. The scientific explanation test data were used to measure pre-service teachers' scientific explanation abilities related to the material of motion, force, and energy that had been learned. The findings of pre-service teachers' scientific explanation test on the pretest and posttest were presented in Table 1.

As shown in Table 1, it can be seen that the average pretest of pre-service teachers was 19.8, with a standard deviation of 12.45 . Meanwhile, the average posttest of preservice teachers was 42.07 , with a standard deviation of 15.97.

Based on Table 1, the claim indicator indicates that the pre-service teachers' pretest score was 33.42, while their posttest score was 39.49. In the evidence indicator, the preservice teacher pretest score was 19.87, and their post-test score was 40.97. Whereas in the explanation indicator, pre-service teachers got 21.00 for their pretest score and 45.75 for their posttest score.

The results of the normality test indicate that the data were normally distributed with a significance of $0.341>0.05$. Since the data were normally distributed, the hypothesis was tested using parametric statistics. Hypothesis testing was done by paired sample t-test method.

The results of the paired sample t-test found that the coefficient of the t-test was 8.28 , with a significance of 0.00 . Thus, it can be concluded that there is a difference between the pre-service teachers' pre-test and posttest in scientific explanation. Based on the results of the average pretest and posttest scores, it can be concluded that the posttest scores are greater than their pretest scores.

Table 1. Scientific explanation T-Test analysis

\begin{tabular}{cccccc}
\hline Sample & N & Mean & SD & t & p-value \\
\hline Pretest & 24 & 19.80 & 12.45 & & \\
Posttest & 24 & 42.07 & 15.97 & 8.28 & $0.000 *$ \\
Mean Gain & - & 22.27 & - & & \\
\hline \multicolumn{2}{l}{$\alpha=0.05 ; \mathrm{df}=46 ;$} & *Significant at $\alpha=0.05$ &
\end{tabular}

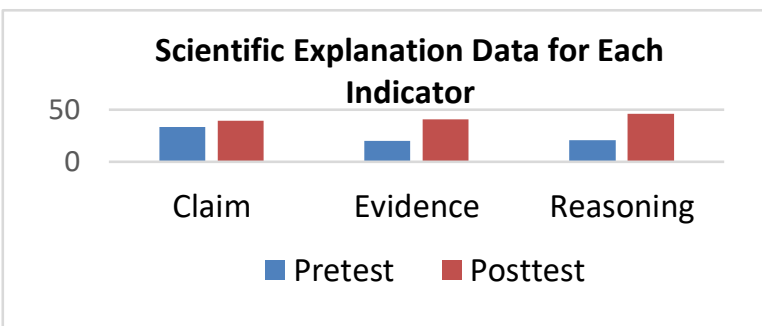

Figure 3. Scientific explanation data for each indicator

\section{Qualitative Data Result}

Qualitative data were obtained from the results of semi-structured interviews and think aloud. Semi-structured interviews and think aloud were conducted on five students who were affected by the intervention in the experimental group.

Pre-service teachers thought that all help links provided were very beneficial. Help links in questions were the provision of escaffolding in e-learning. They felt more familiar with the concept after getting the help links. Additionally, pre-service teachers also considered that the video provided was very helpful in visualizing the concepts to be learned.

Some scaffolding assistance steps provided also helped pre-service teachers solved problems gradually. Pre-service teachers also better understood why an event occurs. However, they did not understand the reasons for their answers. Through scaffolding claims, evidence, and explanation, pre-service teachers found it easier to connect theory with existing problems. 
After understanding how to learn in the lecture process, before lecturing pre-service teachers were enthusiastic about preparing material to be studied. They actively open YouTube, Ruangguru, and Quipper to access material concepts to be studied. This had resulted in pre-service teachers being very active in their opinions in solving problems in class.

During the interview process, pre-service teachers were given one of the problems discussed in the course. When solving problems in the claims and evidence sections, pre-service teachers still remembered the concepts that had been taught correctly. In the explanation stage, they were able to explain the relationship between theory and problems very well and in detail. The explanation in verbal terms was better than their answered during the posttest.

As an example, an instrument in elearning for measuring the pre-service teacher's scientific explanation is shown in Table 2. The pre-service teacher was asked to determine the type of motion experienced by Object 1 and Object 2. Table 2 shows the time and distance data of two objects that are moving from rest conditions.

Table 2. The Time and Distance Data of Two Objects

\begin{tabular}{ccc}
\hline Object & Time $(\mathbf{s})$ & Distance $(\mathbf{m})$ \\
\hline 1 & 1 & 8 \\
& 2 & 16 \\
& 3 & 24 \\
2 & 1 & 3 \\
& 2 & 12 \\
& 3 & 27 \\
\hline
\end{tabular}

The pre-service teacher gave a claim that Object 1 and Object 2 are examples of onedimensional motion with constant velocity and one-dimensional motion with constant acceleration. Evidence was given by the preservice teacher for Object 1, namely constant velocity, zero acceleration, and equal distances in equal intervals of time, while for Object 2, namely, the velocity changes regularly, and the acceleration is constant. The pre-service teacher also gave reasoning. Object 1 experiences a constant velocity of 8 $\mathrm{m} / \mathrm{s}$, and its acceleration is 0 , whereas for Object 2, velocity changes regularly, and its acceleration remains $3 \mathrm{~m} / \mathrm{s}^{2}$. The pre-service teacher's answer to motion material is presented in Figure 4. In evidence Object 1, the pre-service teacher initially responded incomplete, namely changes in the distance of each unit of time and answered incorrectly on reasoning, which is experiencing a velocity of $3 \mathrm{~m} / \mathrm{s}$ (changing regularly). By guiding questions from the lecturer, the preservice teacher could improve her answer toward both evidence and reasoning. The pre-service teacher realized her mistake so that she did an investigation about her response. The pre-service teacher corrected her solution.

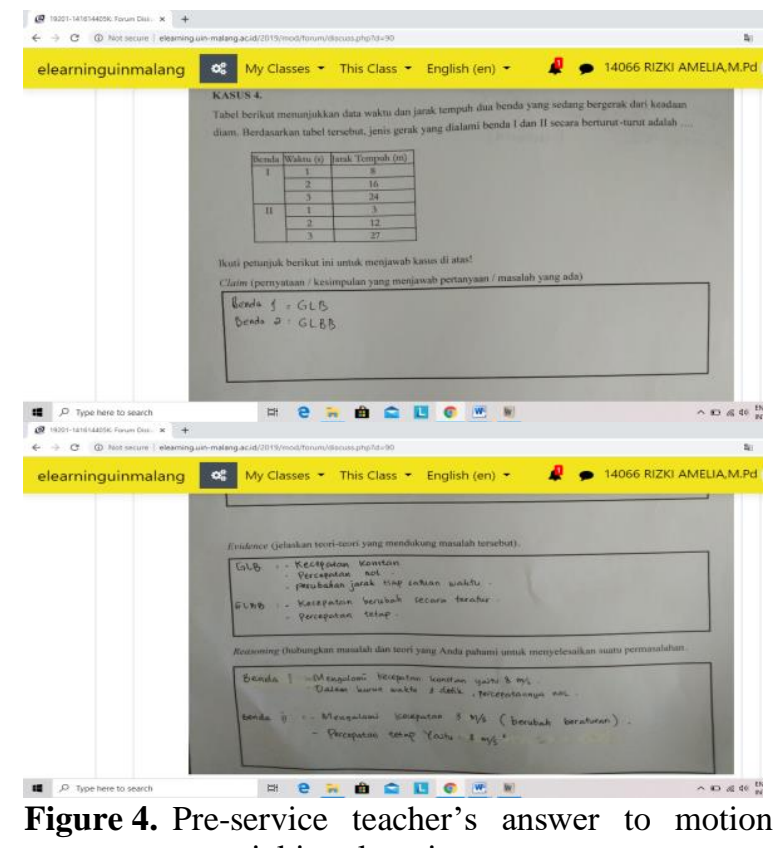
material in e-learning

\section{Discussion}

Based on the data of scientific explanation ability presented in Table 1 and Figure 3, it can be inferred that the scientific explanation ability of pre-service teachers in the claim and evidence aspects data was quite good. However, in the aspect of the explanation, it was still lacking.

In general, pre-service teachers were able to determine the answer when given a case. However, they were often confused when asked why they chose the answer. The 
following is one of the pre-service teacher's answers to one of the questions.

Q: "Suppose you were given two plasticine balls that had the same size, shape, and mass. If one of the plasticine balls was squeezed to flat shape, then what aspect that change it? Give your explanation."

A: "Plasticine. When plasticine is squeezed, it will have a different shape, but the size and mass still stay the same."

The pre-service teacher was indeed correct in making claims and evidence, but they had not explained the explanation. Probosari et al. (2016) stated that most students are right in explaining the facts in a problem, but they are often confused when asked what their reasons are for answering that. Pre-service teachers, in general, can explain claims and evidence well but have difficulty in making explanations (Nurhayati et al., 2016).

Some previous studies are in line with the result of this study. Kim et al. (2018) discussed the students' scientific explanation abilities, especially in constructing arguments in PBL learning with scaffolding. The argument of students who learned by using scaffolding in PBL was better than the argument of students who learned only by PBL. McNeill et al. (2006) revealed that the scientific explanation ability of students increased significantly both in the aspects of claim, evidence, or explanation. However, students who were given scaffolding had a better explanation than those who were given written instructions. Additionally, a study by Oktavianti et al. (2018) reported that the students' scientific explanation ability increases after they learn in blended learning with scaffolding.

Our research differs from previous studies because e-scaffolding in this study is integrated with a worksheet on the web. On the online worksheet, some links are forms of procedural e-scaffolding that help preservice teachers solve problems. Additionally, there are steps of problemsolving in the online worksheet that allows pre-service teachers to give a scientific explanation in the claim, evidence, and reasoning. Scaffolding used in the learning process refers to assistance provided so that students complete assignments that may not be achieved by students (McNeill et al., 2017). The result is in line with research by Kim \& Lim (2019) and Yuriev et al., (2017), which reported that scaffolding improves students' understanding and problem-solving abilities. If no links are provided, students will feel confused in solving the given problem.

\section{CONCLUSION AND SUGGESTION}

The scientific explanation ability is a crucial competency to be possessed by a preservice teacher. Students' scientific explanation ability who studied by using escaffolding in blended learning was higher than the scientific explanation ability of students before using e-scaffolding in blended learning. Based on the interview results, it is known that the response of preservice teachers was very good in the use of e-scaffolding in blended learning. They were also more structured in solving the problem by involving scientific explanation. Therefore, educators should apply an escaffolding strategy to foster pre-service teachers' or students' scientific explanations. For further study, it is imperative to explore the characteristics of e-scaffolding that can promote pre-service teachers (students) scientific explanations optimally.

\section{AUTHOR CONTRIBUTIONS}

RA and IR collected and analysed data. IR conceptualized and reviewing literature. HS reviewing literature, JA prepared research design.

\section{REFERENCES}

Abah, J., Anyagh, P., \& Age, T. (2017). A flipped applied mathematics classroom: Nigerian university students' experience and perceptions. ABACUS, 42(1), 78-87.

Abdullah, W. (2018). Model blended learning dalam meningkatkan efektifitas pembelajaran. Fikrotuna, 7(1), 855- 
866.

Agbo-Egwu, A. O., Abah, J., \& Abakpa, B. (2018). Perceptions of tech-augmented learning in basic mathematics among university students: A case of matrix algebra tools. International Refereed Journal of Arts, Science \& Commerce, 6(1), 121-131.

Al-Ani, W. T. (2013). Blended learning approach using Moodle and student's achievement at Sultan Qaboos University in Oman. Journal of Education and Learning, 2(3), 96-110.

Belland, B. R., Glazewski, K. D., \& Richardson, J. C. (2008). A scaffolding framework to support the construction of evidence-based arguments among middle school students. Educational Technology Research and Development, 56(4), 401-422.

Campbell, L. O. (2016). Concept mapping: An "Instagram" of students' thinking. The Social Studies, 107(2), 74-80.

Creswell, J. W., \& Creswell, J. D. (2018). Research design: Qualitative, quantitative, and mixed methods approaches. Sage Publications, Inc.

Deschacht, N., \& Goeman, K. (2015). The effect of blended learning on course persistence and performance of adult learners: A difference-in-differences analysis. Computers \& Education, 87, 83-89.

Garrison, D. R., \& Vaughan, N. D. (2008). Blended learning in higher education: Framework, principles, and guidelines. John Wiley \& Sons.

Gilles, B., \& Buck, G. (2019). Considering pedagogical practices in higher education: How science methods instructors influence scientific argumentation construction. International Journal of Research in Education and Science, 5(2), 744-757.

González-Howard, M., McNeill, K. L., Marco-Bujosa, L. M., \& Proctor, C. P. (2017). Does it answer the equation or is it French fries?: An exploration of language supports for scientific argumentation. International Journal of Science Education, 39(2), 1-20.

Gunawan, G. (2016). Pemetaan profil kemampuan penalaran calon guru fisika di FKIP Universitas Mataram. Jurnal Pendidikan Fisika Dan Teknologi, 2(1), 1-6.

Hwang, R. H., Lin, H. T., Sun, J. C. Y., Wu, J. (2019). Improving learning achievement in science education for elementary school students via blended learning. International Journal of Online Pedagogy and Course Design, 9(2), 44-62.

Kim, J. Y., \& Lim, K. Y. (2019). Promoting learning in online, ill-structured problem solving: The effects of scaffolding type and metacognition level. Computers \& Education, 138, 116-129.

Kim, N. J., Belland, B. R., \& Walker, A. E. (2018). Effectiveness of computerbased scaffolding in the context of problem-based learning for STEM education: Bayesian meta-analysis. Educational Psychology Review, 30(2), 397-429.

Law, K. M. Y., Geng, S., \& Li, T. (2019). Student enrollment, motivation and learning performance in a blended learning environment: The mediating effects of social, teaching, and cognitive presence. Computers and Education, 136, 1-12.

Lee, H., Pallant, A., Pryputniewicz, S., Lord, T., Mulholland, M., \& Liu, O. L. (2019). Automated text scoring and real-time adjustable feedback: Supporting revision of scientific arguments involving uncertainty. Science Education, 103(3), 590-622.

Loper, S., McNeill, K. L., González-Howard, M., Marco-Bujosa, L. M., \& O'Dwyer, L. M. (2019). The impact of multimedia education curriculum materials (MECMs) on teachers' beliefs about scientific argumentation. Technology, Pedagogy and Education, 28(2), 173190. 
López-Pérez, M. V., Pérez-López, M. C., \& Rodríguez-Ariza, L. (2011). Blended learning in higher education: Students' perceptions and their relation to outcomes. Computers \& Education, 56(3), 818-826.

McNeill, K. L. (2011). Elementary students' views of explanation, argumentation, and evidence, and their abilities to construct arguments over the school year. Journal of Research in Science Teaching, 48(7), 793-823.

McNeill, K. L., \& Krajcik, J. (2008). Scientific explanations: Characterizing and evaluating the effects of teachers' instructional practices on student learning. Journal of Research in Science Teaching: The Official Journal of the National Association for Research in Science Teaching, 45(1), 53-78.

McNeill, K. L., Lizotte, D. J., Krajcik, J., \& Marx, R. W. (2006). Supporting students' construction of scientific explanations by fading scaffolds in instructional materials. The Journal of the Learning Sciences, 15(2), 153-191.

Miles, M. B., \& Huberman, A. M. (1994). Qualitative data analysis: An expanded sourcebook. Sage Publications Ltd.

Nurhayati, N., Yuliati, L., \& Mufti, N. (2016). Pola penalaran ilmiah dan kemampuan penyelesaian masalah sintesis fisika. Jurnal Pendidikan: Teori, Penelitian, Dan Pengembangan, 1(8), 1594-1597.

Oktavianti, E., Handayanto, S. K., Wartono, W., \& Saniso, E. (2018). Students' scientific explanation in blended physics learning with e-scaffolding. Jurnal Pendidikan IPA Indonesia, 7(2), 181-186.

Pallant, A., \& Lee, H.-S. (2015). Constructing scientific arguments using evidence from dynamic computational climate models. Journal of Science Education and Technology, 24(2-3), 378-395.

Probosari, R. M., Ramli, M., Harlita, Indrowati, M., \& Sajidan. (2016). Profil keterampilan argumentasi ilmiah mahasiswa Pendidikan Biologi FKIP UNS pada mata kuliah anatomi tumbuhan. Bioedukasi: Jurnal Pendidikan Biologi, 9(1), 29-33.

Raes, A., Schellens, T., De Wever, B., \& Vanderhoven, E. (2012). Scaffolding information problem solving in webbased collaborative inquiry learning. Computers \& Education, 59(1), 82-94.

Rofiki, I., Nusantara, T., Subanji, \& Chandra, T. D. (2017a). Exploring local plausible reasoning: The case of inequality tasks. Journal of Physics: Conference Series, 943(1), 12002.

Rofiki, I., Nusantara, T., Subanji, \& Chandra, T. D. (2017b). Reflective plausible reasoning in solving inequality problem. IOSR Journal of Research \& Method in Education, 7(1), 101-112.

Sengul, O., Zhang, X., Leroux, A. J. (2019). A multi-level analysis of students' teacher and family relationship on academic achievement in schools. International Journal of Education Methodology, 5(1), 117-133.

Von Aufschnaiter, C., Erduran, S., Osborne, J., \& Simon, S. (2008). Arguing to learn and learning to argue: Case studies of how students' argumentation relates to their scientific knowledge. Journal of Research in Science Teaching: The Official Journal of the National Association for Research in Science Teaching, 45(1), 101-131.

Yapici, I. U., \& Akbayin, H. (2012). The effect of blended learning model on high school students' biology achievement and on their attitudes towards the internet. Turkish Online Journal of Educational TechnologyTOJET, 11(2), 228-237.

Yuriev, E., Naidu, S., Schembri, L. S., \& Short, J. L. (2017). Scaffolding the development of problem-solving skills in chemistry: Guiding notice students out of dead ends and false starts. Chemistry Education Research and Practice, 18(3), 486-504. 